\title{
Transfection of Cells from Patients with Leukocyte Adhesion Deficiency with an Integrin $\beta$ Subunit (CD18) Restores Lymphocyte Function-associated Antigen-1 Expression and Function
}

\author{
Margaret L. Hibbs, Andrew J. Wardlaw, Steven A. Stacker, Donald C. Anderson, ${ }^{\star}$ Alice Lee, ${ }^{\ddagger}$ \\ Thomas M. Roberts, ${ }^{\ddagger}$ and Timothy A. Springer \\ The Center for Blood Research and Department of Pathology, Harvard Medical School, Boston, Massachusetts 02115; \\ ${ }^{\ddagger}$ Division of Neoplastic Disease Mechanisms, Dana-Farber Cancer Institute, Boston, Massachusetts 02115; and \\ *Texas Children's Clinical Care Center, Houston, Texas 77054
}

\begin{abstract}
Leukocyte adhesion deficiency (LAD) is an inherited immunodeficiency disease that is characterized by the deficient expression of the leukocyte adhesion glycoproteins lymphocyte function-associated antigen-1 (LFA-1), Mac-1, and p150,95. This loss of expression is attributed to heterogeneous defects in the common $\beta$ subunit shared by these glycoproteins. Here we demonstrate that expression of the LFA-1 $\alpha \beta$ heterodimer in EBV-transformed B lymphoblastoid cells from LAD patients can be recovered after transfection with the $\beta$ subunit cDNA contained in an EBV-based vector. Four patients with differing severities of LAD comprising three distinct classes of mutations were studied. Flow cytometry analysis of stably transfected patient cells revealed near normal levels of expression of both the $\alpha$ and $\beta$ chains of LFA-1, and immunoprecipitation studies confirmed that fully processed $\alpha$ and $\beta$ chains were being expressed at the cell surface. In addition, Northern analysis of mRNA expression also demonstrated that the transfected LAD patient cells were expressing high quantities of exogenous $\beta$ subunit mRNA. Functional studies such as homotypic adhesion and adhesion to a purified counterreceptor for LFA-1, intracellular adhesion molecule-1, demonstrated that LFA-1 function had been restored in the stably transfected LAD patient cell lines. These studies unequivocally show that the defect in cells from patients with LAD is in the leukocyte integrin $\beta$ subunit. (J. Clin. Invest. 1990. 85:674-681.) leukocyte integrin $\bullet$ adhesion receptor $\bullet$ adhesion protein deficiency $\bullet$ gene therapy
\end{abstract}

\section{Introduction}

The leukocyte integrins, lymphocyte function-associated antigen-1 (LFA-1), ${ }^{1}$ Mac-1, and p150,95 are heterodimers consisting of a unique $\alpha$ subunit noncovalently associated with a

Address reprint requests to Dr. T. A. Springer, Center for Blood Research, 800 Huntington Avenue, Boston, MA 02115.

Received for publication 28 September 1989 and in revised form 7 November 1989.

1. Abbreviations used in this paper: CMV, cytomegalovirus; LAD, leukocyte adhesion deficiency; LFA-1, lymphocyte function-associated antigen-1.

J. Clin. Invest.

(c) The American Society for Clinical Investigation, Inc.

0021-9738/90/03/0674/08 \$2.00

Volume 85, March 1990, 674-681 common $\beta$ subunit (1). The importance of this family of glycoproteins in adhesion-related functions has been emphasized by the discovery of a rare human genetic disease called leukocyte adhesion deficiency (LAD; reviewed extensively in reference 2). Patients with LAD are deficient in their cell surface expression of LFA-1, Mac-1, and p150,95. The characteristic features of LAD are recurrent life-threatening bacterial and fungal infections, gingivitis, severely impaired pus formation, and chronic leukocytosis. Lymphocytes, monocytes, and granulocytes from patients with LAD show a wide range of defects in adhesion-related functions such as adhesion to endothelial cells, cell migration, cell-mediated cytolysis, and antigen presentation $(2,3)$. On the basis of quantitative differences in expression of the LFA-1 glycoprotein family, severe (expressing $<1 \%$ of normal levels of $\alpha \beta$ complexes) and moderate (expressing 3-10\% of normal levels) deficiency phenotypes have been defined (4). The degree of glycoprotein deficiency directly relates to the severity of the clinical complications. Moderately deficient patients, although often severely afflicted, can live to adulthood; however, patients suffering from the severe form of the disease usually die early in childhood from overwhelming infections.

Several lines of evidence have suggested that the defect in LAD is due to the common $\beta$ subunit. In every patient studied to date, expression of all three leukocyte integrins has been found to be deficient. Studies using mouse $\times$ human lymphocyte hybrids constructed from an LFA- $1^{+}$mouse T lymphoma and the lymphocytes of one patient demonstrated that surface expression of the human LFA- $1 \alpha$ subunit but not the $\beta$ subunit from LAD patient cells could be rescued by the formation of interspecies $\alpha \beta$ complexes, indicating that the $\alpha$ subunit from this patient was competent for surface expression but that the $\beta$ subunit was not (5). Biosynthetic studies of the $\alpha$ and $\beta$ subunits of the leukocyte integrins indicate that they are synthesized as precursors containing high-mannose $N$-linked oligosaccharides $(1,6)$. Association of the $\alpha$ subunit precursor with the $\beta$ subunit precursor is necessary for additional carbohydrate processing and transport to the cell surface. Association with an $\alpha$ subunit was not detectable in any of the LAD patients who synthesize a $\beta$ subunit precursor (7-9). After the isolation of cDNA clones encoding the $\beta$ subunit of the leukocyte integrins $(10,11)$ it was demonstrated that heterogeneous mutations in the common $\beta$ subunit give rise to $\operatorname{LAD}(8,12)$. To date, five distinct classes of mutations have been identified. Two classes of mutations affect the gross structure of the $\beta$ subunit giving rise to either aberrantly large or small $\beta$ subunit (8). One class of mutation results in no detectable mRNA or protein precursor, while a fourth class of mutation is characterized by the synthesis of trace amounts of $\beta$ subunit precursor 
and low levels of message $(8,12)$. A fifth class of mutation results in synthesis of a $\beta$ subunit that appears normal by SDS-PAGE, but fails to associate with the $\alpha$ subunit $(8,9,12$, 13). This class of mutation could be due to point mutations in $\alpha$ or $\beta$, or could affect a third protein required for their assembly. We have recently studied the genetic basis for the defect in four related patients of the moderate deficiency phenotype who synthesize an aberrantly small form of the common $\beta$ subunit (14). Aberrant splicing in $95 \%$ of the mRNA caused by a mutation in a $5^{\prime}$ splice site resulted in a 30 amino acid deletion in a highly conserved region of the $\beta$ subunit. The low level of normally spliced mRNA was responsible for a small amount of normal cell surface protein, and hence the moderate deficiency phenotype.

This study was undertaken as a final confirmation that mutations in the $\beta$ subunit are responsible for LAD and as an assessment of the feasibility of gene therapy for patients with LAD. In this study we used the $\beta$ subunit $\mathrm{cDNA}$ clone inserted into an EBV-based expression vector to transfect EBV-transformed B lymphoblastoid cells from two patients with LAD who synthesized normal amounts of $\beta$ subunit mRNA, one patient who synthesized an aberrantly large protein precursor, and one patient who produced no detectable $\beta$ subunit mRNA. We demonstrated that near normal levels of LFA-1 $\alpha \beta$ complexes can be recovered at the cell surface in cell lines derived from all of these patients and showed that these reconstituted molecules are functional in binding ICAM-1, a cellular counterreceptor for LFA-1, in two different adhesion assays. These studies provide direct evidence that mutations in the common leukocyte integrin $\beta$ subunit cause LAD.

\section{Methods}

MAbs. All MAbs used in this study have been described previously. TS1/18 and TS1/22 are inhibitory mouse IgG1 MAbs specific for human LFA- $1 \beta$ and $\alpha$ chains, respectively (15). TS $2 / 6$ is an inhibitory mouse MAb specific for the human LFA- $1 \alpha$ subunit (15). RR $1 / 1$ is a mouse IgG1 MAb specific for human ICAM-1 (16). W6/32 is a mouse MAb specific for HLA-A,B.

Cell lines. Cell lines derived from four unrelated LAD patients with differing severities of LAD were used in this study. The clinical histories of patients 1 and 2 (BBN and SLA cell lines [4]) and patient 12 (KOS cell line [17]) have been detailed previously. Patients 1, 2, and 12 were phenotyped as severely deficient. Patient 12 produced no detectable $\beta$ subunit mRNA or protein precursor, patient 1 synthesized an aberrantly large $\beta$ subunit precursor, and patient 2 produced normal levels of $\beta$ subunit mRNA and detectable precursor (8). EBV-transformed $B$ cell lines have previously been established from these patients (8). An EBV-transformed B lymphoblastoid cell line derived from a Caucasian patient from Denmark (EKM cell line [18]) was also used. This patient will be referred to as patient 15 . Patient 15 was of the moderately deficient phenotype, produced normal amounts of $\beta$ subunit mRNA, and synthesized normal-sized $\beta$ precursors (Wardlaw, A. J., and T. A. Springer, unpublished observations). The EBV-transformed B lymphoblastoid lines JY and $\mathrm{CO} 3(8)$ are established cell lines derived from healthy individuals. All cell lines were maintained in RPMI 1640 medium supplemented with $20 \%$ FCS, 2 mM glutamine, and $50 \mu \mathrm{g} / \mathrm{ml}$ gentamycin (complete medium) at $37^{\circ} \mathrm{C}$ in a humidified atmosphere of $5 \% \mathrm{CO}_{2}$.

Plasmid constructions. The $\beta$ subunit insert in $\lambda g t 11$ (18.1.1; [10]) was removed by complete digestion with Nae I and partial digestion with Eco RI. The Nae I site is at nucleotide 2529 in the $\mathbf{3}^{\prime}$ untranslated region of the $\beta$ subunit. This fragment, which contains $72 \mathrm{bp}$ of $5^{\prime}$ untranslated sequence and 140 bp of $3^{\prime}$ untranslated sequence, was ligated with Bgl II linkers after blunting of the Eco RI sticky end with
T4 polymerase, and subcloned into the Bgl II site in the polylinker of pGC, a pBR322-based plasmid. The $\beta$ subunit was then transferred into the Bst XI site in the transient expression vector CDM8 for preliminary expression studies using Bst XI linkers after removal from pGC with Bgl II and filling in the ends with Klenow fragment $(19,20)$. To construct a vector containing the $\beta$ subunit cDNA which could be directly selected and stably maintained as episomes in mammalian cells (Fig. 1), the Nhe I-Kpn I fragment containing the M13 origin, cytomegalovirus (CMV)/T7 RNA polymerase promoter, $\beta$ subunit cDNA, and splice and polyadenylation signals was excised from CDM8 and subcloned into Xba I/Kpn I-digested p205118a, a generous gift of Dr. B. Seed. The plasmid p205118a is a derivative of p205 (21), into which a polycloning site donated by pUC18 has been subcloned between the col E1 bacterial origin of replication and the hygromycin phosphotransferase ( $h p h$ ) gene in p205 (Seed, B., personal communication). The unique restriction sites in the polylinker are Hind III, Kpn I, Sal I, Sph I, and Xba I. The segment of DNA donated by $\mathrm{p} 205118$ a contains the EBV origin for plasmid replication (ori $\mathrm{P}$ ), the EBNA-1 gene, which ensures episomal replication in non-EBV positive cell lines, and the $h p h$ gene, which confers resistance to hygromycin B in mammalian cells. This hybrid vector was designated pEBCB1 (Fig. 1).

Transfection of human B lymphoblastoid cell lines. LAD patient EBV-transformed cell lines in the logarithmic growth phase were pelleted, washed with Hepes-buffered saline ( $20 \mathrm{mM}$ Hepes, $\mathrm{pH}$ 7.05, 137 $\mathrm{mM} \mathrm{NaCl}, 5 \mathrm{mM} \mathrm{KCl}, 0.7 \mathrm{mM} \mathrm{Na}_{2} \mathrm{HPO}_{4}, 6 \mathrm{mM}$ dextrose) and resuspended in $800 \mu \mathrm{l}$ Hepes-buffered saline at a concentration of $2 \times 10^{7} /$ $\mathrm{ml}$. DNA $(30 \mu \mathrm{g})$ in $10 \mathrm{mM}$ Tris- $\mathrm{HCl} \mathrm{pH} \mathrm{8.0/1} \mathrm{mM} \mathrm{EDTA} \mathrm{was} \mathrm{mixed}$ with the cells and the suspension then electroporated at a voltage of $280 \mathrm{~V}$ and a capacitance of $1,000 \mu \mathrm{F}(22)$. The transfected cells were diluted into $12 \mathrm{ml}$ complete RPMI 1640 medium and transferred to $25-\mathrm{cm}^{2}$ tissue culture flasks. Selection for hygromycin B-resistant cells was started $48 \mathrm{~h}$ posttransfection with hygromycin B (CalbiochemBehring Corp., San Diego, CA) at a concentration of $200 \mu \mathrm{g} / \mathrm{ml}$.

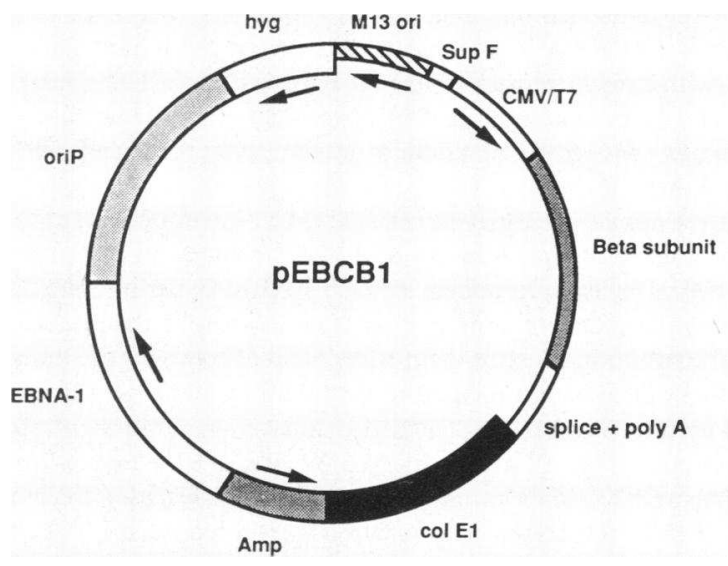

Figure 1. Schematic representation of pEBCB1. pEBCB1 is a composite of the EBV-based vector p205118a and the transient expression vector CDM8. The portion donated by $\mathrm{p} 205118 \mathrm{a}$ is represented by the thick line and includes the Escherichia coli hph gene (hyg), the EBV oriP, a functional segment of the EBV nuclear antigen 1 gene $(E B N A-1)$, ampicillin-resistance gene $(A m p)$, and bacterial origin of replication $(\mathrm{col} \mathrm{El})$. The thin line represents the segment from CDM8 and shows the M13 origin of replication (M13 ori), tyrosine tRNA amber-suppressor gene (Sup F), CMV/T7 RNA polymerase promoter $(C M V / T 7), \beta$ subunit $C D N A$, and splice and polyadenylation signals. pEBCB1 was generated by ligating the Xba I-Kpn I fragment of p205118a with the Nhe I-Kpn I fragment of CDM8 containing the $\beta$ subunit cDNA. The Xba I site from the polylinker of p205118a and the Nhe I site adjacent to the M13 origin in CDM8 were destroyed upon ligation. Arrows indicate direction of transcription. 
FACS analysis. Expression of LFA-1 was quantitated 6 wk posttransfection by indirect immunofluorescence (23). MAb (50 $\mu \mathrm{l}$ of a 1:100 dilution of ascites) was incubated with $50 \mu \mathrm{l}$ of cells $\left(10^{7}\right.$ cells $\left./ \mathrm{ml}\right)$ for $30 \mathrm{~min}$ on ice. The cells were washed twice with PBS/0.5\% BSA, then resuspended in $50 \mu$ l of a 1:10 dilution of FITC-conjugated goat anti-mouse IgG (Zymed, San Francisco, CA) and incubated on ice for a further $30 \mathrm{~min}$. After washing twice with PBS/0.5\% BSA, cells were fixed with $1 \%$ paraformaldehyde in PBS. The fluorescence of labeled cells was analyzed on an Epics V flow cytometer.

Cell labeling and immunoprecipitation. EBV-transformed B cell lines in log phase of growth were washed three times in PBS and resuspended to $10^{7}$ cells $/ \mathrm{ml} .1 \mathrm{mCi}$ of $\mathrm{Na}^{125} \mathrm{I}$ was added to $2 \mathrm{ml}$ of cells and the entire mixture transferred to Iodo-gen (Pierce Chemical Co., Rockford, IL)-coated glass vials for 10 min with intermittent agitation (24). Free ${ }^{125}$ I was quenched by the addition of RPMI/10\% FCS and the cells were washed three times in the same medium. The cell pellets were lysed in $1 \mathrm{ml}$ of $1 \%$ Triton X-100, $10 \mathrm{mM}$ Tris-HCl, pH 8.0, 150 $\mathrm{mM} \mathrm{NaCl}, 1 \%$ hemoglobin, $1 \mathrm{mM}$ iodoacetamide, $1 \mathrm{mM}$ PMSF, 0.24 trypsin inhibitory units/ml aprotinin, and $0.025 \% \mathrm{NaN}_{3}$ for $45 \mathrm{~min}$ at $4^{\circ} \mathrm{C}$. Nuclei were pelleted at $12,000 \mathrm{~g}$ for $15 \mathrm{~min}$ at $4^{\circ} \mathrm{C}$ and the lysates were precleared overnight with $100 \mu$ l packed bovine Ig coupled to Sepharose. Immunoprecipitation was carried out by incubating equal amounts of lysate with $20 \mu \mathrm{l}$ of either anti- $\beta$ subunit MAb (TS1/18), anti-LFA- $1 \alpha$ subunit MAb (TS1/22), anti-ICAM-1 MAb (RR1/1), or bovine Ig (control) coupled to Sepharose (Pharmacia Fine Chemicals, Piscataway, $\mathrm{NJ}$ ) for $2 \mathrm{~h}$ at $4^{\circ} \mathrm{C}$. The immunoprecipitates were washed three times with $25 \mathrm{mM}$ Tris- $\mathrm{HCl}, \mathrm{pH} 8.0,150 \mathrm{mM} \mathrm{NaCl}$, and $0.1 \%$ Triton X-100, twice with $25 \mathrm{mM}$ Tris- $\mathrm{HCl}, \mathrm{pH} 8.0$, and $150 \mathrm{mM}$ $\mathrm{NaCl}$, and once with $50 \mathrm{mM}$ Tris- $\mathrm{HCl}, \mathrm{pH}$ 8.0. Immunoprecipitates were subjected to SDS-PAGE under reducing conditions (25).

Northern analysis. Total mRNA was isolated from EBV-transformed cell lines using guanidinium isothiocyanate and centrifugation in $\mathrm{CsCl}$ gradients (26). Northern blotting was carried out as described $(10,27)$. Briefly, 15- $\mu \mathrm{g}$ aliquots were denatured and run in a denaturing $1 \%$ agarose gel containing formaldehyde. Ethidium bromide staining demonstrated that comparable amounts of RNA were used for each cell line. The RNA was transferred to nylon membranes and hybridized with a nick-translated 700-bp Bam HI-Eco RI fragment from the $5^{\prime}$ end of the beta subunit cDNA overnight at $65^{\circ} \mathrm{C}$. The filters were washed at $65^{\circ} \mathrm{C}$ in $0.2 \times$ standard saline citrate, $0.1 \%$ SDS and autoradiographed.

Qualitative homotypic aggregation assay. Cell lines were washed and resuspended to a concentration of $2 \times 10^{6}$ cells $/ \mathrm{ml}$ in complete medium. $100 \mu \mathrm{l}$ cells were added to each well of a flat-bottomed, 96-well microtiter plate containing $50 \mu \mathrm{l}$ of either neat MAb supernatant or a 1:200 dilution of ascites, and either $50 \mu \mathrm{l}$ of complete medium or $50 \mu \mathrm{l}$ of complete medium containing $200 \mathrm{ng} / \mathrm{ml}$ phorbol, $12-\mathrm{my}-$ ristate, 13-acetate (PMA). This yielded a final concentration of 50 $\mathrm{ng} / \mathrm{ml}$ PMA and $2 \times 10^{5}$ cells/well. W6/32 was used as a binding control MAb and TS2/6 as an inhibitory MAb. Cells were allowed to settle at $37^{\circ} \mathrm{C}$, and the degree of aggregation was scored visually at 120 $\mathrm{min}(28)$. In all cases the assays were performed in duplicate and read blindly by two independent observers. Aggregates were scored on a scale of 1 to 5 , where 1 indicated that $<10 \%$ of the cells were in aggregates, 2 that $10-50 \%$ of cells were aggregated, 3 that $50-90 \%$ of the cells were in aggregates, 4 that up to $100 \%$ of the cells were aggregated in loose clusters, and 5 that all cells were in large compact aggregates.

Purification of ICAM-1. ICAM-1 was purified by affinity chromatography on RR1/1-Sepharose from lysates of hairy cell spleens (29). Briefly, hairy cell spleens $(30 \mathrm{~g})$ were lysed in $650 \mathrm{ml}$ of $1 \%$ Triton $\mathrm{X}-100,10 \mathrm{mM}$ Tris- $\mathrm{HCl}, \mathrm{pH} 8.0,150 \mathrm{mM} \mathrm{NaCl}, 5 \mathrm{mM}$ iodoacetamide, $0.5 \mathrm{mM}$ PMSF, $1 \mathrm{mM}$ diisopropylfluorophosphate, 0.24 trypsin inhibitory units $/ \mathrm{ml}$ aprotinin, and $0.025 \% \mathrm{NaN}_{3}$ for $45 \mathrm{~min}$ at $4^{\circ} \mathrm{C}$. Nuclei and aggregates were removed by centrifugation for $30 \mathrm{~min}$ at $3,500 \mathrm{rpm}$ followed by $90 \mathrm{~min}$ at $10,000 \mathrm{rpm}$ and filtration through filter paper (\# 1; Whatman Laboratory Products Inc., Clifton, NJ). The lysate was precleared with $5 \mathrm{ml}$ packed bovine Ig-Sepharose for $2 \mathrm{~h}$ at $4^{\circ} \mathrm{C}$, then loaded onto the $R R 1 / 1$ column and run through at a flow rate of $0.5 \mathrm{ml} / \mathrm{min}$. The column was then washed as previously described (30) and eluted with $50 \mathrm{mM}$ triethylamine, $\mathrm{pH} 12.5,150 \mathrm{mM}$ $\mathrm{NaCl}$, and $1 \%$ octylglucoside. Fractions were neutralized immediately with 0.2 vol of $1 \mathrm{M} \mathrm{Tris-HCl,} \mathrm{pH} 6.7 / 1 \%$ octylglucoside, snap-frozen in liquid nitrogen, and stored at $-70^{\circ} \mathrm{C}$.

Binding of transfectants to purified, plastic-bound ICAM-1. Stable transfectants were tested for their ability to bind to purified ICAM-1 coated onto plastic (31). Purified ICAM-1 was absorbed to wells of a PVC microtiter plate (Flow Laboratories, Inc., McLean, VA) at a predetermined concentration of 4,000 sites $/ \mu \mathrm{m}^{2}$ for $2 \mathrm{~h}$ at room temperature or overnight at $4^{\circ} \mathrm{C}$ in $20 \mathrm{mM}$ Tris- $\mathrm{HCl}, \mathrm{pH} 8.0,150 \mathrm{mM} \mathrm{NaCl}$ and $2 \mathrm{mM} \mathrm{MgCl}_{2}$. Nonspecific sites were then blocked for $1 \mathrm{~h}$ at room temperature with $20 \mathrm{mM}$ Tris- $\mathrm{HCl}, \mathrm{pH} 8.0,150 \mathrm{mM} \mathrm{NaCl}, 2 \mathrm{mM}$ $\mathrm{MgCl}_{2}$, and $1 \%$ human serum albumin, after which the plate was washed with $\mathrm{PBS} / 5 \% \mathrm{FCS} / 2 \mathrm{mM} \mathrm{MgCl}_{2}$ (assay media). Cells were labeled for $1 \mathrm{~h}$ at $37^{\circ} \mathrm{C}$ with $100 \mu \mathrm{Ci} \mathrm{Na}{ }^{51} \mathrm{CrO}_{4}$, then washed three times with assay media. In all cases cells were pretreated with antiICAM-1 MAb (RR 1/1; 1:500 dilution of ascites) for $30 \mathrm{~min}$ at $4^{\circ} \mathrm{C}$ to prevent PMA-stimulated aggregation of cells. Unbound RR 1/1 MAb used for pretreating cells was washed out before the assay. Antibodytreated, ${ }^{51} \mathrm{Cr}$-labeled cells $\left(50 \mu \mathrm{l}\right.$ of $\left.10^{6} \mathrm{cells} / \mathrm{ml}\right)$ were added to wells containing $50 \mu \mathrm{l}$ of a $1: 2$ dilution of MAb supernatant with or without PMA at $100 \mathrm{ng} / \mathrm{ml}$. W6/32 was used as the binding control MAb and $\mathrm{RR} 1 / 1$ as the inhibitory MAb. The cells were centrifuged onto the solid phase ICAM- 1 at $10 \mathrm{~g}$ for $5 \mathrm{~min}$ at $4^{\circ} \mathrm{C}$, incubated at $37^{\circ} \mathrm{C}$ for $10 \mathrm{~min}$, and then the wells washed immediately by four complete aspirations through an 18-gauge needle. Before washing, visual inspection of the wells was performed to ensure that no homotypic aggregation of the cells had occurred. Bound cells were released with $0.1 \mathrm{~N} \mathrm{NaOH}, 1 \%$ SDS and subjected to gamma counting. ICAM-1 site numbers were determined using saturated amounts of ${ }^{125} \mathrm{I}$-anti-ICAM-1 MAb and calculated assuming bivalent binding of the MAb.

\section{Results}

Expression of the LFA-1 $\alpha / \beta$ heterodimer in patient $L A D$ cells. We chose to construct an EBV-based vector to achieve stable LFA-1 expressing transfectants in LFA-1-deficient LAD patient cell lines, as others have demonstrated that these type of vectors yield stable gene expression with very high efficiency (32-35). The $\beta$ subunit cDNA was subcloned into the transient expression vector CDM8, in which gene expression is driven by the strong CMV promoter (19) and its ability to be expressed was initially demonstrated in COS cells by cotransfection with the LFA-1 $\alpha$ subunit (not shown). We then constructed the vector pEBCB1 (Fig. 1) by subcloning a fragment of CDM8 containing the $\beta$ subunit CDNA as well as the M13 origin, $\mathrm{CMV}$ promoter, and polyadenylation signals into the polycloning site of the EBV-based vector p205118a (see Methods). EBV-transformed B lymphoblastoid cell lines from four unrelated patients with different classes of mutations and phenotypes were used for transfection. Cell lines derived from patients 1,2 , and 15 produced normal levels of $\beta$ subunit mRNA and protein precursor; the patient $1 \beta$ subunit precursor was variously reported as aberrantly large (8; Wardlaw, A. J., unpublished observations) or normal in size (13). Patient 12 produced no detectable $\beta$ subunit mRNA or protein precursor (8). EBV lines from patients 2 and 12 lacked any detectable cell surface LFA- $1 \alpha$ or $\beta$ subunits, and the line from patient 15 expressed small amounts (Fig. 2) in agreement with previous typing as severe or moderate deficiency, respectively $(4,17,18)$. Patient 1 appeared to express small amounts of surface LFA-1 (Fig. 2); patient 1 was previously characterized as severely deficient based on expression of LFA-1, Mac-1, and 


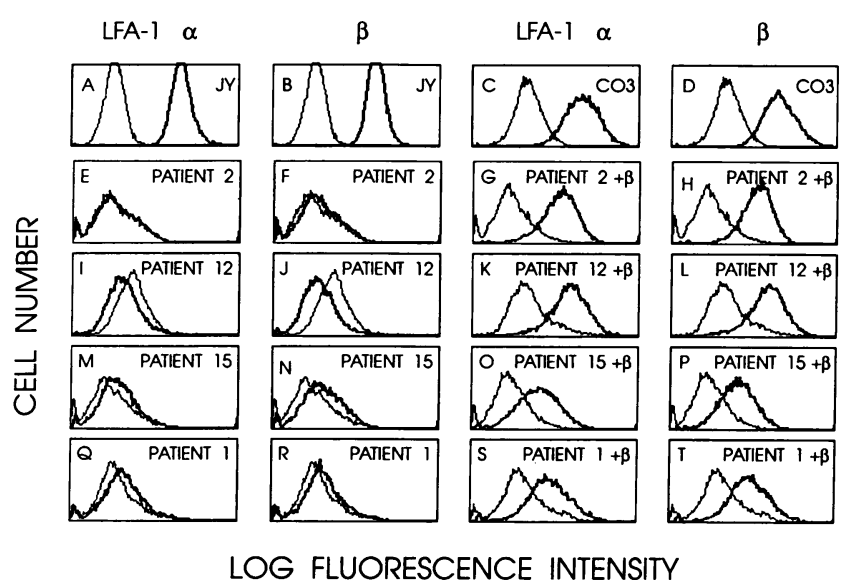

Figure 2. Immunofluorescence flow cytometric analysis of LAD patient cell lines stably transfected with the $\beta$ subunit cDNA and control cells. The EBV-transformed B lymphoblastoid cell lines JY $(A$, $B), \operatorname{CO} 3(C, D)$, patient $2(E, F)$, patient $2+\beta(G, H)$, patient $12(I$, $J)$, patient $12+\beta(K, L)$, patient $15(M, N)$, patient $15+\beta(O, P)$, patient $1(Q, R)$, and patient $1+\beta(S, T)$ were stained as indicated with either anti-LFA-1 $\alpha$ (TS1/22) or anti- $\beta$ (TS1/18) subunit MAbs (thick line) or with a nonbinding control antibody X63 (thin line).

p150,95 on neutrophils $(4,18)$. Cells resistant to hygromycin B were selected $48 \mathrm{~h}$ posttransfection. 2-3 wk later a pure population of hygromycin-resistant cells expressing LFA-1 was obtained. Cells were tested for expression of LFA-1 by flow cytometry using both anti-LFA-1 $\alpha$ (TS1/22) and anti- $\beta$ subunit (TS1/18)-specific MAbs (Fig. 2). After transfection with the $\beta$ subunit cDNA, expression of both the $\alpha$ and $\beta$ subunits of
LFA-1 was recovered in all four LAD patient cell lines (Fig. 2). The level of expression was comparable to that in the $\mathrm{CO} 3$ line, which is the most appropriate control since it was EBVtransformed from a healthy individual in parallel to the patient lines. However, JY cells, a high LFA-1-expressing cell line, expressed more LFA-1 than did the transfectants.

$S D S-P A G E$ analysis of transfectants. To confirm that fully processed LFA- $1 \alpha$ and $\beta$ subunits were being expressed on the cell surface of the stable transfectants, three of the four transfected patient cell lines were analyzed by surface labeling and immunoprecipitation (Fig. 3). LFA- ${ }^{+}$LAD transfected cells derived from patients 2,12 , and 15 expressed normal-sized LFA- $1 \alpha$ and $\beta$ chains as demonstrated by immunoprecipitation with both an anti-LFA-1 $\alpha$ subunit MAb (Fig. 3, $C, E$, and $G$; lane 2 ) and an anti- $\beta$ subunit MAb (Fig. $3, C, E$, and $G$; lane 3 ) and comparison with LFA-1 immunoprecipitated from JY cells (Fig. $3 A$, lanes 2 and 3 ). All nontransfected patient cells were deficient in cell surface expression of mature LFA-1 (Fig. 3, B, D, and $F$; lanes 2 and 3 ) but had normal levels of expression of ICAM-1, which is a 97,000-D glycoprotein (Fig. $3, B, D$, and $F$; lane 4 ). A low but discernible amount of iodinated LFA- $1 \alpha$ precursor (170,000-D), which was presumably labeled after some cell lysis during the labeling procedure, was detected in the nontransfected cell lines by immunoprecipitation with an anti-LFA- $1 \alpha$ subunit-specific MAb (Fig. 3, $B, D$, and $F$; lane 2). Previous studies showed that patients 1,2 , and 15 synthesized a $\beta$ subunit precursor that was precipitable with an anti- $\beta$ subunit serum (8; Wardlaw, A. J., unpublished observations); the $\beta$ subunit MAb used in these studies (TS1/18) only recognized $\beta$ when present in an $\alpha \beta$ complex.

Northern blot analysis of transfectants. Total RNA from nontransfected and stably transfected LAD patient cell lines
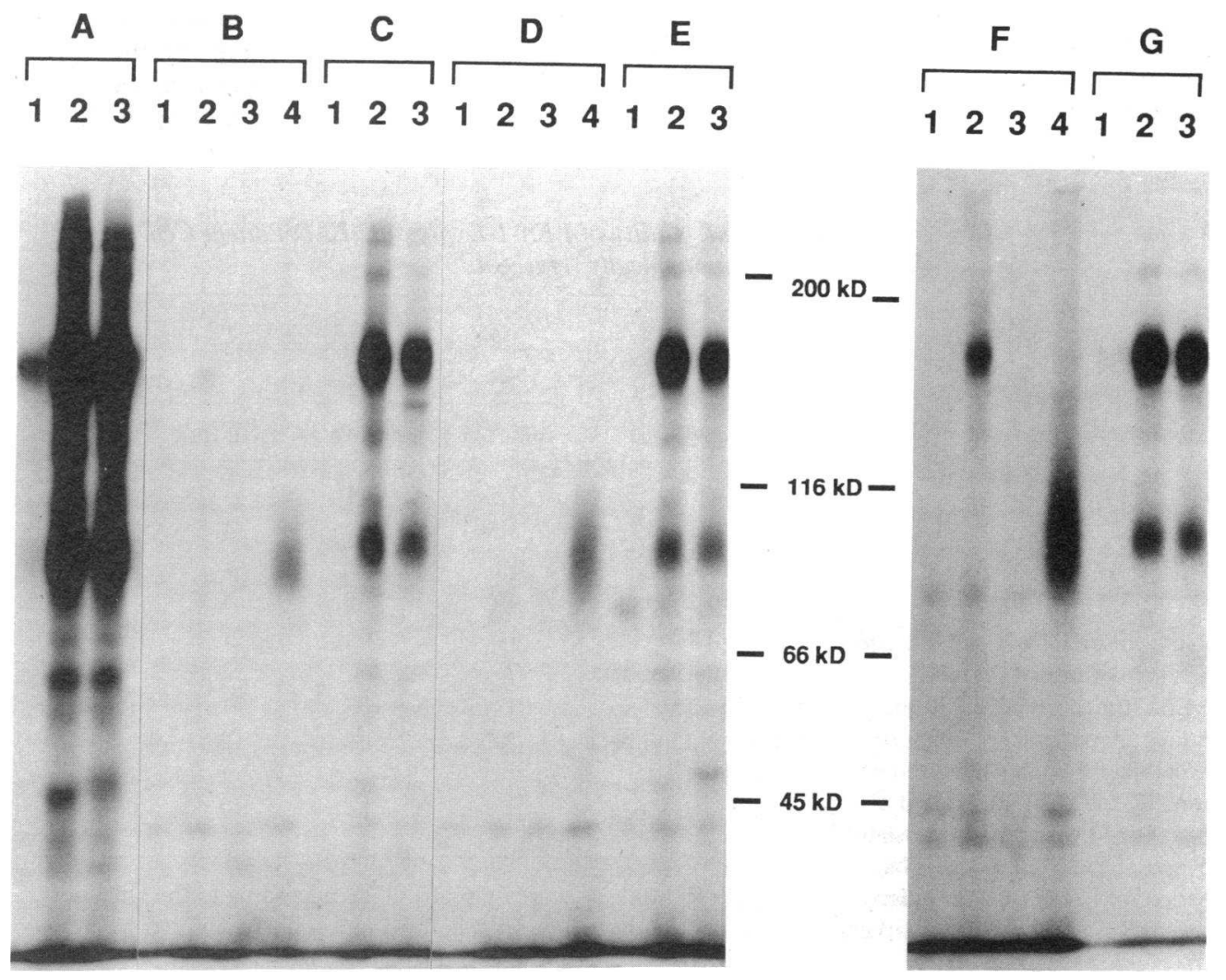

Figure 3. ${ }^{125} \mathrm{I}$-Labeled surface proteins immunoprecipitated from LAD patient cell lines stably transfected with the $\beta$ subunit cDNA. Triton $X-100$ lysates of ${ }^{125}$ I-labeled JY $(A)$, patient $2(B)$, patient 2 stably transfected with the $\beta$ subunit cDNA $(C)$, patient $12(D)$, patient $12+\beta(E)$, patient 15 $(F)$, and patient $15+\beta(G)$ were immunoprecipitated with bovine Ig-Sepharose (lane I), anti-LFA- $1 \alpha$ subunit MAbSepharose (lane 2), or anti- $\beta$ subunit MAb-Sepharose (lane 3). Anti-ICAM-1 MAb-Sepharose (lane 4) was used as a positive control to demonstrate normal expression of ICAM-1 in nontransfected LAD patient cell lines. Molecular weight markers are indicated. 
was probed with a nick-translated cDNA probe from the $5^{\prime}$ end of the $\beta$ subunit (Fig. 4). With the exception of patient 12, who produced no detectable message (Fig. 4, lane 6$)(8)$, nontransfected LAD patient cells (Fig. 4, lanes 2, 4, and 8) expressed relatively normal levels of $\beta$ subunit message when compared with healthy control cells (CO3; Fig. 4, lane 1). In the transfected cell lines (Fig. 4, lanes 3, 5, 7, and 9), a transcript derived from the $\beta$ subunit expression vector was present that was larger than the endogenous $\beta$ subunit mRNA. The predicted size of $\beta$ subunit message transcribed in $\mathrm{pEBCB} 1$ was $\sim 3.4$ $\mathrm{kb}$, which is slightly larger than the single $\beta$ subunit mRNA species of $3 \mathrm{~kb}$ inherent in $\mathrm{CO} 3$ and nontransfected LAD patient cells. Interestingly, different levels of expression of the exogenous $\beta$ subunit mRNA were apparent. Transfected cells from patient 12 (Fig. 4, lane 7) expressed significantly higher amounts of $\beta$ subunit message than did any of the other transfected cells. Patient 15 expressed the lowest amount of $\beta$ message (Fig. 4, lane 5), while patients 1 and 2 expressed intermediate levels (Fig. 4, lanes 3 and 9).

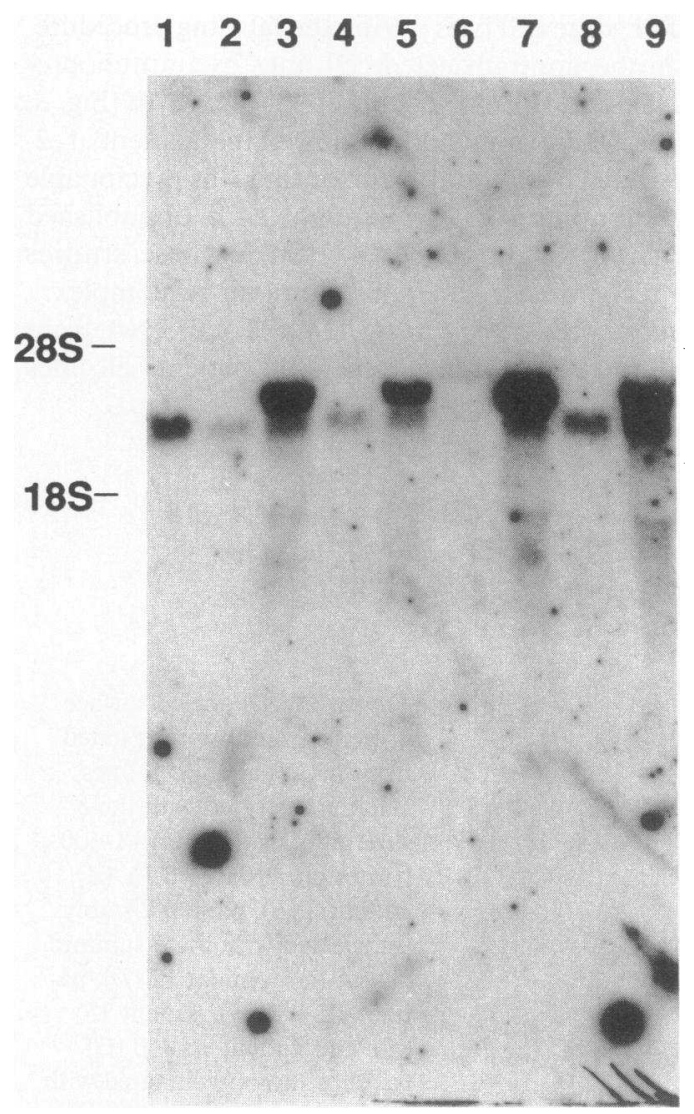

Figure 4. Northern blot analysis of $\beta$ subunit mRNA in cell lines derived from LAD patients stably transfected with the $\beta$ subunit cDNA. Total RNA isolated from the EBV-transformed B lymphoblastoid cells $\mathrm{CO} 3$ (lane 1 ), patient 2 (lane 2 ), patient 2 stably transfected with $\beta$ subunit cDNA (lane 3 ), patient 15 (lane 4 ), patient 15 $+\beta$ (lane 5 ), patient 12 (lane 6 ), patient $12+\beta$ (lane 7), patient 1 (lane 8 ), and patient $1+\beta$ (lane 9 ) was probed with a nick-translated Bam HI-Eco RI fragment from the $5^{\prime}$ end of the $\beta$ subunit cDNA. Equivalent amounts of RNA were loaded into each track as judged by ethidium bromide staining. $28 \mathrm{~S}$ and $18 \mathrm{~S}$ ribosomal RNA markers are indicated.
Transfected LAD patient cells can homotypically aggregate. As a means of testing whether functional capability had been restored in the LFA-1-expressing LAD patient cell lines, PMA-stimulated aggregation of the transfectants was examined (Table I; Fig. 5). Stable LFA- ${ }^{+}$LAD transfectants could form aggregates both in the presence and absence of PMA; however, PMA enhanced the rate and magnitude of the response (Table I). This response could be inhibited by the addition of anti-LFA-1 MAb (Table I; Fig. 5). The TS2/6 LFA-1 $\mathrm{MAb}$ was not as efficient in inhibiting a strong aggregation response, but could totally inhibit weaker responses. The magnitude of the response of the LAD transfectants compared favorably with the expression of LFA-1 on their cell surface. Transfected LAD EBV-transformed cells from patient 2, the highest LFA-1-expressing transfectant, aggregated strongly in the presence of PMA and when PMA was omitted from the media (Table I; Fig. 5). The other cell lines aggregated well in the presence of PMA but to a lesser degree. In contrast, there was no aggregation of the nontransfected LFA- $1^{-}$EBV-transformed cells from the three severely deficient patients or the one moderately deficient patient after $2 \mathrm{~h}$ incubation at $37^{\circ} \mathrm{C}$ (Table I).

LFA-1-expressing LAD patient cells bind ICAM-1. Recently it has been demonstrated that LFA-1-expressing cell lines can bind to purified ICAM-1 absorbed to polystyrene microtiter plates (31). We adopted this approach to examine the ability of two of the stable LFA- $1^{+}$LAD transfectants to function in binding to ICAM-1 and to investigate whether binding could be upregulated by phorbol esters (Fig. 6). In the absence of PMA, LFA- $1^{+}$transfectants derived from patients 2 and 12 could bind to purified ICAM-1, and this binding was totally abrogated by anti-ICAM-1 MAb (Fig. 6, $A$ and $B$ ) and anti-LFA-1 MAb (not shown). As has been shown previously with JY cells (31), PMA could dramatically increase adhesion of the transfectants to ICAM-1 (Fig. 6). This interaction could also be inhibited by anti-ICAM-1 MAb (Fig. 6) and antiLFA-1 MAb (not shown). In contrast, nontransfected LAD patient cell lines showed no binding to ICAM-1 above back-

Table I. Ability of LFA-1-Expressing LAD Patient Cell Lines to Homotypically Aggregate

\begin{tabular}{|c|c|c|c|c|}
\hline \multirow[b]{3}{*}{ Cell line } & \multicolumn{4}{|c|}{ Aggregation score* } \\
\hline & \multicolumn{2}{|c|}{-PMA } & \multicolumn{2}{|c|}{+ PMA } \\
\hline & Anti-HLA & Anti-LFA-1 & Anti-HLA & Anti-LFA-1 \\
\hline JY & 4.5 & 3.5 & 5 & 2.5 \\
\hline $\mathrm{CO} 3$ & 3.5 & 2 & 4 & 2.5 \\
\hline Patient 2 & 1 & 1 & 1 & 1 \\
\hline Patient $2+$ beta & 4 & 2.5 & 4 & 1.5 \\
\hline Patient 12 & 1 & 1 & 1 & 1 \\
\hline Patient $12+$ beta & 2 & 1 & 2.5 & 1 \\
\hline Patient 15 & 1 & 1 & 1 & 1 \\
\hline Patient $15+$ beta & 2 & 1 & 2.5 & 1 \\
\hline Patient 1 & 1 & 1 & 1 & 1 \\
\hline Patient $1+$ beta & 1 & 1 & 2 & 1 \\
\hline
\end{tabular}

* Aggregation was scored visually at $2 \mathrm{~h}$ according to the scale outlined in Methods. The scores of two independent observers were averaged. 
A
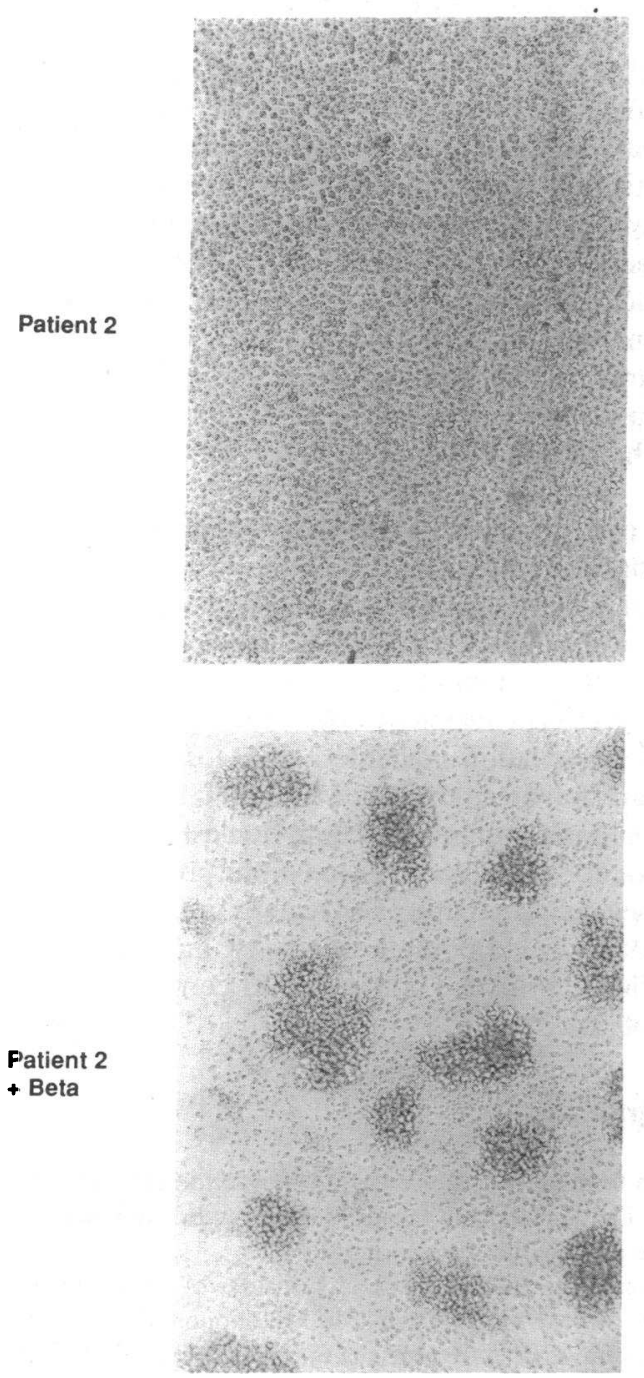

B
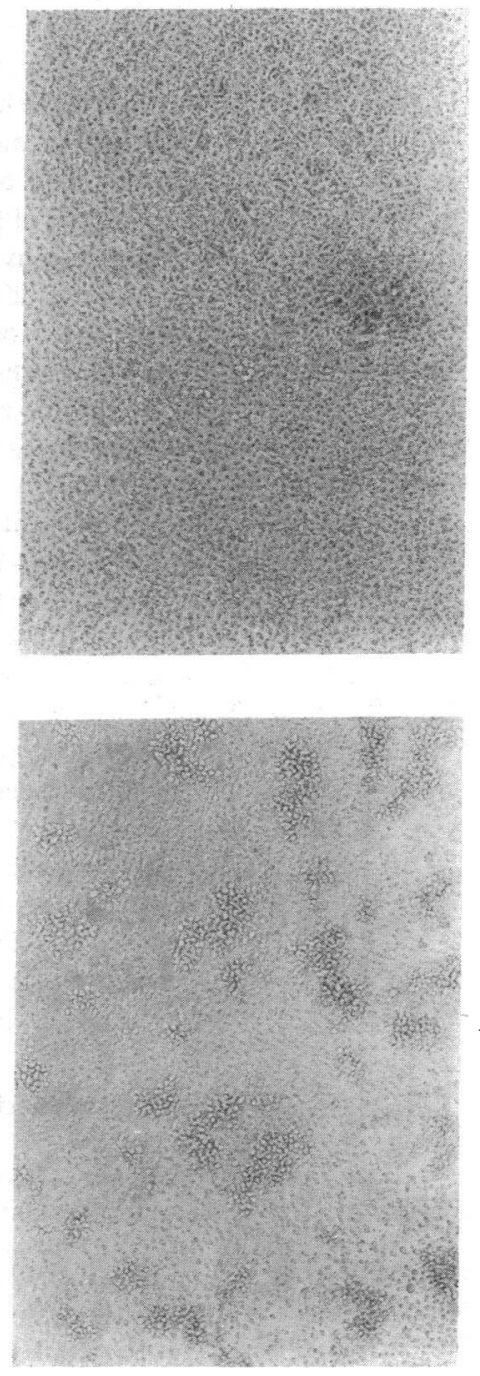

Figure 5. Homotypic aggregation of a LAD patient cell line stably transfected with the $\beta$ subunit and the parental LFA-1 ${ }^{-}$LAD patient cell line. Nontransfected cell lines derived from patient 2 and cell lines from patient 2 stably transfected with the $\beta$ subunit cDNA were incubated with PMA $(A)$ or with PMA + anti-LFA-1 MAb $(B)$ for $2 \mathrm{~h}$ at $37^{\circ} \mathrm{C}$. ground levels of adhesion in either the presence or absence of PMA (Fig. 6).

\section{Discussion}

In this study we have demonstrated that functional LFA-1 can be reconstituted in cell lines derived from a number of patients with LAD, a disease characterized by deficient expression of the leukocyte adhesion glycoproteins $(2,3,8)$. In all patient cell lines studied, LFA-1 expression and function could be restored upon transfection with the leukocyte integrin $\beta$ subunit, and Northern blotting confirmed that exogenous $\beta$ subunit mRNA was being expressed. LAD patient cell lines characterized as having different classes of mutations and different deficiency phenotypes were used in these studies. Although evidence already implies that LAD is secondary to mutations in the common $\beta$ subunit $(5,8,14)$, it is conceivable that patients who synthesize the $\beta$ subunit which appears grossly normal by SDS-PAGE may have point mutations in the $\alpha$ subunits rather than the $\beta$ subunit, or may have a mutation in a protein required for their assembly. It was therefore important to ascertain whether LFA-1 expression could be recovered in these cell lines after stable transfection with a $\beta$ subunit cDNA from a healthy individual. The results presented here have demonstrated that the defect in three unrelated LAD patients (patients 1, 2, and 15) who synthesize normal levels of $\beta$ subunit message and $\beta$ subunit precursor is in the $\beta$ subunit gene and not in the $\alpha$ subunits or a molecule required for $\alpha \beta$ assembly or transport to the cell surface. LFA-1 surface expression and function was also recovered in a line derived from patient 12 , who has been characterized as synthesizing no $\beta$ subunit mRNA or protein precursor; however, although we can say that the defect in this patient lies with the $\beta$ subunit, we can not rule out the possibility that in this patient the defect could be in a molecule regulating $\beta$ subunit expression rather than within the $\beta$ subunit gene itself. These results provide the final confirmation that the defect in LAD patients lies with the $\beta$ subunit.

Flow cytometry and immunoprecipitation analysis of stably transfected cell lines derived from the four different LAD patients confirmed that LFA-1 expression had been restored and that the correct sized LFA-1 $\alpha \beta$ heterodimers were present at the cell surface. The level of LFA-1 expression in the different transfectants was variable but compared favorably 
A

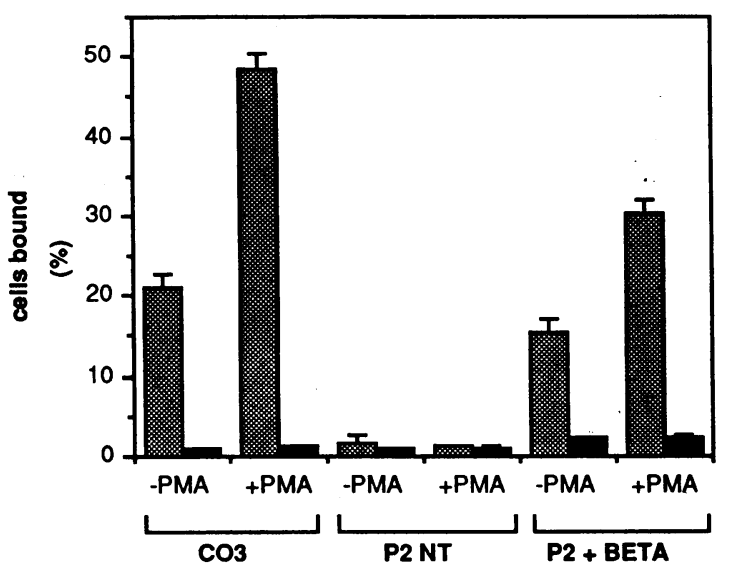

B

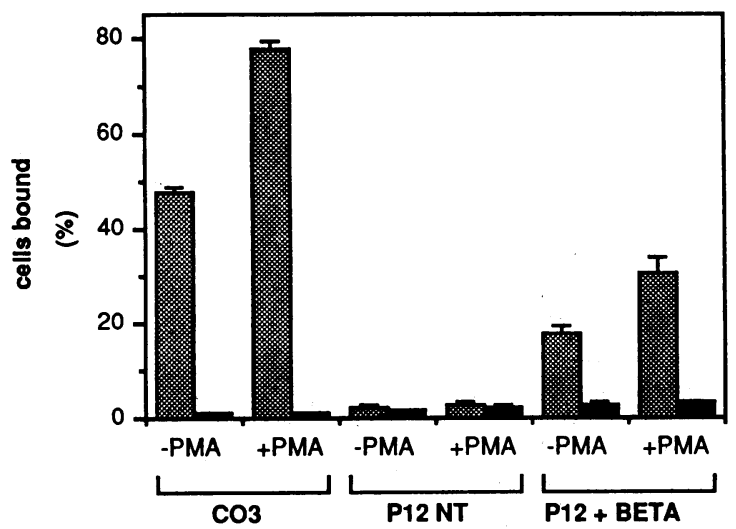

Figure 6. Binding of LAD patient cell lines stably transfected with the $\beta$ subunit cDNA and their parental LFA- $1^{-}$LAD patient cell lines to ICAM-1-coated plastic. $A,{ }^{51} \mathrm{Cr}$-Labeled nontransfected and stably transfected cell lines derived from patient 2 ( $P 2 N T$ and $P 2$ $+B E T A$, respectively) and $\mathrm{CO} 3$ cells (control) were centrifuged onto ICAM-1-coated plastic at $10 \mathrm{~g}$ for $5 \mathrm{~min}$, then incubated for $10 \mathrm{~min}$ at $37^{\circ} \mathrm{C}$ in the presence of anti-HLA-A,B (W6/32; hatched bars) or anti-ICAM-1 MAb (RR1/1; solid bars). Results are expressed as percentage of input cells bound. Error bars represent \pm 1 SD. $B$, Same as $A$, except that nontransfected and stably transfected cell lines from patient $12(P 12)$ were used in the assay.

with the control cell line $\mathrm{CO} 3$, which had been derived from a healthy individual. The amount of LFA- 1 expressed by the transfected cell lines as determined by flow cytometry correlated well with the degree of homotypic aggregation seen. The highest LFA-1-expressing transfectant (cell line from patient 2 stably transfected with the $\beta$ subunit) aggregated to a similar degree as control cells but faster and to a greater degree than those expressing lower levels. Cell lines expressing lower levels of LFA-1 were not as effective as JY or $\mathrm{CO} 3$ in the homotypic aggregation assay. Transfected cell lines derived from all four patients were able to bind to the LFA-1 counterreceptor, ICAM-1, although those expressing lower levels of LFA-1 were not as efficient (Fig. 6; data not shown). In addition, the avidity of LFA-1 for ICAM-1 could be increased in all four trans- fected cell lines with phorbol esters, indicating that intracellular signaling pathways are intact in these cells (31).

The studies presented here, which demonstrate that LFA-1 expression and function can be restored in LAD patient cell lines with the leukocyte integrin $\beta$ subunit $\mathrm{cDNA}$, indicate that this genetic disease is likely to be a good candidate for gene therapy. We anticipate that even low levels of expression of this family of glycoproteins should greatly reduce the clinical complications associated with LAD in patients of the severe phenotype, as moderately deficient LAD patients who express only 3-10\% of normal levels of LFA-1, Mac-1, and p150,95 have a significantly better prognosis than severely deficient patients who express $<1 \%$ of normal levels $(2,3)$. In addition, heterozygotes who have as low as $50 \%$ expression have normal function.

The ability of EBV-transformed B lymphoblastoid cell lines derived from patients with LAD to have LFA-1 expression and function restored upon stable transfection with the $\beta$ subunit cDNA now makes for an extremely useful model to study mutants of the $\beta$ subunit gene. This system would be superior to using foreign recipient cells which may lack the appropriate phosphorylation machinery or cytoskeletal components necessary for precisely tuned function. Thus, stable expression of $\beta$ subunit mutants in B lymphoblastoid cell lines would enable not only the determination of the precise contact sites between the $\alpha$ and $\beta$ subunits and regions in the $\beta$ subunit which contribute to ligand binding specificity, but regions responsible for PMA-stimulated adhesion and contact sites for cytoskeletal proteins.

\section{Acknowledgments}

The authors wish to thank Mr. E. Luther for flow cytometric analysis of transfectants, Dr. B. Seed for the p205118a vector, and Mr. M. Dustin for advice and helpful discussions.

This work was supported by National Institutes of Health (NIH) grants CA-31798, and AI-21163. Dr. Hibbs was supported by a grant from The Jane Coffin Childs Memorial Fund for Medical Research. Dr. Wardlaw was a recipient of an NIH International Fogarty Training award, a Potter Fellowship, and a grant from the Pathological Society of Great Britain and Ireland.

\section{References}

1. Sanchez-Madrid, F., J. A. Nagy, E. Robbins, P. Simon, and T. A. Springer. 1983. A human leukocyte differentiation antigen family, with distinct $\alpha$-subunits and a common $\beta$-subunit. The lymphocyte function-associated antigen (LFA-1), the C3bi complement receptor (OKM1/Mac-1), and the p150,95 molecule. J. Exp. Med. 158:17851803.

2. Anderson, D. C., and T. A. Springer. 1987. Leukocyte adhesion deficiency: an inherited defect in the Mac-1, LFA-1, and p150,95 glycoproteins. Annu. Rev. Med. 38:175-194.

3. Springer, T. A., and D. C. Anderson. 1986. Leukocyte complement receptors and adhesion proteins in the inflammatory response: insights from an experiment of nature. Biochem. Soc. Symp. 51:47-57.

4. Anderson, D. C., F. C. Schmalstieg, M. J. Finegold, B. J. Hughes, R. Rothlein, L. J. Miller, S. Kohl, M. F. Tosi, R. L. Jacobs, T. C. Waldrop, A. S. Goldman, W. T. Shearer, and T. A. Springer. 1985. The severe and moderate phenotypes of heritable Mac-1, LFA-1 deficiency: their quantitative definition and relation to leukocyte dysfunction and clinical features. J. Infect. Dis. 152:668-689.

5. Marlin, S. D., C. C. Morton, D. C. Anderson, and T. A. Springer. 1986. LFA-1 immunodeficiency disease. Definition of the genetic de- 
fect and chromosomal mapping of alpha and beta subunits of the lymphocyte function-associated antigen 1 (LFA-1) by complementation in hybrid cells. J. Exp. Med. 164:855-867.

6. Sastre, L., T. K. Kishimoto, C. Gee, T. Roberts, and T. A. Springer. 1986. The mouse leukocyte adhesion proteins Mac-1 and LFA-1: studies on mRNA translation and protein glycosylation with emphasis on Mac-1. J. Immunol. 137:1060-1065.

7. Springer, T. A., W. S. Thompson, L. J. Miller, F. C. Schmalstieg, and D. C. Anderson. 1984. Inherited deficiency of the Mac-1, LFA-1, p150,95 glycoprotein family and its molecular basis. J. Exp. Med. 160:1901-1918

8. Kishimoto, T. K., N. Hollander, T. M. Roberts, D. C. Anderson, and T. A. Springer. 1987. Heterogenous mutations in the beta subunit common to the LFA-1, Mac-1, and p150,95 glycoproteins cause leukocyte adhesion deficiency. Cell. 50:193-202.

9. Dimanche, M. T., F. Le Deist, A. Fischer, M. A. Arnaout, C Griscelli, and B. Lisowska-Grospierre. 1987. LFA-1 beta chain synthesis and degradation in patients with leukocyte adhesion deficiency. Eur. J. Immunol. 17:417-419.

10. Kishimoto, T. K., K. O’Connor, A. Lee, T. M. Roberts, and T. A. Springer. 1987. Cloning of the beta subunit of the leukocyte adhesion proteins: homology to an extracellular matrix receptor defines a novel supergene family. Cell. 48:681-690.

11. Law, S. K. A., J. Gagnon, J. E. K. Hildreth, C. E. Wells, A. C. Willis, and A. J. Wong. 1987. The primary structure of the beta subunit of the cell surface adhesion glycoproteins LFA-1, CR3 and p150,95 and its relationship to the fibronectin receptor. $E M B O$ (Eur. Mol. Biol. Organ.) J. 6:915-919.

12. Dimanche-Boitrel, M. T., A. Guyot, G. De Saint-Basile, A. Fischer, C. Griscelli, and B. Lisowska-Grospierre. 1988. Heterogeneity in the molecular defect leading to the leukocyte adhesion deficiency. Eur. J. Immunol. 18:1575-1579.

13. Dana, N., L. K. Clayton, D. G. Tennen, M. W. Pierce, P. J. Lachmann, S. A. Law, and M. A. Arnaout. 1987. Leukocytes from four patients with complete or partial Leu-CAM deficiency contain the common beta-subunit precursor and beta-subunit messenger RNA. $J$. Clin. Invest. 79:1010-1015.

14. Kishimoto, T.' K., K. O'Connor, and T. A. Springer. 1989. Leukocyte adhesion deficiency: aberrant splicing of a conserved integrin sequence causes a moderate deficiency phenotype. J. Biol. Chem. 264:3588-3595.

15. Sanchez-Madrid, F., A. M. Krensky, C. F. Ware, E. Robbins, J. L. Strominger, S. J. Burakoff, and T. A. Springer. 1982. Three distinct antigens associated with human $\mathrm{T}$ lymphocyte-mediated cytolysis: LFA-1, LFA-2, and LFA-3. Proc. Natl. Acad. Sci. USA. 79:7489-7493.

16. Rothlein, R., M. L. Dustin, S. D. Marlin, and T. A. Springer. 1986. A human intercellular adhesion molecule (ICAM-1) distinct from LFA-1. J. Immunol. 137:1270-1274.

17. Kobayashi, K., K. Fujita, F. Okino, and T. Kajii. 1984. An abnormality of neutrophil adhesion: autosomal recessive inheritance associated with missing neutrophil glycoproteins. Pediatrics. 73:606610 .

18. Wang, P., and T. A. Springer. 1987. Steroid treatment of a patient with moderate Mac-1, LFA-1 deficiency: Eur. J. Clin. Invest. 17:A66. (Abstr.)
19. Seed, B. 1987. An LFA-3 cDNA encodes a phospholipid-linked membrane protein homologous to its receptor CD2. Nature (Lond.). 329:840-842

20. Aruffo, A., and B. Seed. 1987. Molecular cloning of a CD28 cDNA by a high efficiency COS cell expression system. Proc. Natl. Acad. Sci. USA. 84:8573-8577.

21. Yates, J. L., N. Warren, and B. Sugden. 1985. Stable replication of plasmids derived from Epstein-Barr virus in various cells various mammalian cells. Nature (Lond.). 313:812-815.

22. Chu, G., H. Hayakawa, and P. Berg. 1987. Electroporation for the efficient transfection of mammalian cells with DNA. Nucleic Acids Res. 15:1311-1326.

23. Miller, L. J., R. Schwarting, and T. A. Springer. 1986. Regulated expression of the Mac-1, LFA-1, p150,95 glycoprotein family during leukocyte differentiation. J. Immunol. 137:2891-2900.

24. Fraker, P. J. and J. C. Speck. 1978. Protein and cell membrane iodinations with a sparingly soluble chloroamide, 1,3,4,6-tetrachloro3,6-diphenyl glycoluril. Biochem. Biophys. Res. Commun. 80:849857.

25. Laemmli, U. K., and M. Favre. 1973. Maturation of the head of bacteriophage T4. J. Mol. Biol. 80:575-599.

26. Chirgwin, J. M., A. E. Przybyla, R. J. MacDonald, and W. J. Rutter. 1979. Isolation of biologically active ribonucleic acid from sources enriched in ribonuclease. Biochemistry. 18:5294-5299.

27. Maniatis, T., E. F. Fritsch, and J. Sambrook. 1982. Molecular Cloning: A Laboratory Manual. Cold Spring Harbor Laboratory, Cold Spring Harbor, NY. 545 pp.

28. Rothlein, R., and T. A. Springer. 1986. The requirement for lymphocyte function-associated antigen 1 in homotypic leukocyte adhesion stimulated by phorbol ester. J. Exp. Med. 163:1132-1149.

29. Marlin, S. D., and T. A. Springer. 1987. Purified intercellular adhesion molecule-1 (ICAM-1) is a ligand for lymphocyte functionassociated antigen 1 (LFA-1). Cell. 51:813-819.

30. Dustin, M. L., and T. A. Springer. 1988. Lymphocyte function associated antigen-1 (LFA-1) interaction with intercellular adhesion molecule-1 (ICAM-1) is one of at least three mechanisms for lymphocyte adhesion to cultured endothelial cells. J. Cell Biol. 107:321-331.

31. Dustin, M. L., and T. A. Springer. 1989. T cell receptor crosslinking transiently stimulates adhesiveness through LFA-1. Nature (Lond.). 341:619-624.

32. Sugden, B., K. Marsh, and J. Yates. 1985. A vector that replicates as a plasmid and can be efficiently selected in B-lymphoblasts transformed by Epstein-Barr virus. Mol. Cell. Biol. 5:410-413.

33. Tykocinski, M. L., H.-K. Shu, D. J. Ayers, E. I. Walter, R. R. Getty, R. K. Groger, C. A. Hauer, and M. E. Medof. 1988. Glycolipid reanchoring of T-lymphocyte surface antigen CD2 using the 3 ' end sequence of decay-accelerating factor's mRNA. Proc. Natl. Acad. Sci. USA. 85:3555-3559.

34. Hambor, J. E., C. A. Hauer, H. K. Shu, R. K. Groger, D. R. Kaplan, and M. L. Tykocinski. 1988. Use of an Epstein-Barr virus episomal replicon for anti-sense RNA-mediated gene inhibition in a human cytotoxic T-cell clone. Proc. Natl. Acad. Sci. USA. 85:40104014

35. Margolskee, R. F., P. Kavathas, and P. Berg. 1988. Epstein-Barr virus shuttle vector for stable episomal replication of cDNA expression libraries in human cells. Mol. Cell. Biol. 8:2837-2847. 